\title{
Development of Boron-Cluster-Based Progesterone Receptor Antagonists Bearing a Pentafluorosulfanyl $\left(\mathrm{SF}_{5}\right)$ Group
}

\author{
Shuichi Mori, Nozomi Tsuemoto, Tomoya Kasagawa, Eiichi Nakano, Shinya Fujii, and \\ Hiroyuki Kagechika* \\ Institute of Biomaterials and Bioengineering, Tokyo Medical and Dental University (TMDU); 2-3-10 Kanda- \\ Surugadai, Chiyoda-ku, Tokyo 101-0062, Japan. \\ Received June 23, 2019; accepted September 6, 2019
}

The progesterone receptor (PR) plays an important role in various physiological processes, especially in the female reproductive system, and abnormalities of PR function are associated with several diseases, including some types of cancer. Non-steroidal PR ligands are of interest as candidate drugs for treatment of PR-related diseases without the serious adverse effects that may be caused by steroidal ligands. For the development of non-steroidal PR ligands, both a hydrophobic backbone and a polar functional group corresponding to the 3-carbonyl group of progesterone, which interacts with GIn725 and Arg766 of the PR-ligand binding domain, are critically important. We previously showed that carborane is a useful hydrophobic pharmacophore for $\mathrm{PR}$ antagonists, and in this work, we introduced the pentafluorosulfanyl $\left(\mathrm{SF}_{5}\right)$ group as a novel polar functional group of carborane-based non-steroidal PR antagonists. All the synthesized $\mathrm{SF}_{5}-$ containing carborane derivatives exhibited PR-antagonistic activity at micromolar or submicromolar concentration. Among them, compounds 11 are potent progesterone antagonists with submicromolar $\mathrm{IC}_{50}$ values.

Key words progesterone receptor; antagonist; carborane; pentafluorosulfanyl group

\section{Introduction}

The progesterone receptor $(\mathrm{PR})$ is a member of the nuclear receptor superfamily. Its endogenous agonist, progesterone (1, Fig. 1), binds to the PR ligand-binding domain (PR-LBD), resulting in the activation of transcription of target genes, whose promoters contain PR-response elements. ${ }^{1)} \mathrm{PR}$ is involved in the regulation of various physiological processes, especially those involved in the female reproductive system, including regulation of uterine cell proliferation/differentiation, ${ }^{2,3)}$ mammary gland growth/differentiation, ${ }^{4)}$ the ovulation cycle, ${ }^{5)}$ and sexual behaviors. ${ }^{6}$ Various synthetic PR agonists and antagonists have been clinically employed ${ }^{7-9)}$ for contraception, induction of abortion, hormone replacement therapy, and treatment of gynecological disorders. The synthetic PR antagonist mifepristone (2, Fig. 1) is a representative abortifacient, ${ }^{10)}$ and is also effective in the treatment of endometriosis, ${ }^{11)}$ uterine leiomyoma, ${ }^{12)}$ and breast cancer. ${ }^{13)}$ However, all PR ligands in clinical use, including $\mathbf{2}$, possess a steroidal structure, which may cause significant adverse effects due to cross-activity with other steroid hormone receptors. ${ }^{14)}$ To avoid these adverse effects, several non-steroidal PR ligands have been developed, such as tanaproget $(3)^{15)}$ and sulfonamide derivative $4^{16)}$ (Fig. 1). In the design of such ligands, a polar functional group and a hydrophobic pharmacophore that mimics the steroid skeleton are critically important for the interaction of the ligands with the PR-LBD. In the case of $\mathbf{3}, \mathrm{X}$-ray crystallographic analysis of the complex of $\mathbf{3}$ with the PR-LBD revealed that the cyano group of 3 interacts with Gln725 and Arg766 of PR-LBD, which are the same amino acid residues that interact with the 3-carbonyl group of $\mathbf{1}^{15)}$

In the previous study, we developed non-steroidal PR antagonists bearing a boron-cluster carborane as the hydrophobic core structure. ${ }^{17-20)}$ Carboranes, or more precisely dicarbacloso-dodecaboranes $\left(\mathrm{C}_{2} \mathrm{~B}_{10} \mathrm{H}_{12}\right)$, are carbon-containing boron clusters with an icosahedral cage structure, and there are three isomers, depending on the positions of the two carbon atoms, that is, ortho-, meta-, and para-carborane. ${ }^{21)}$ Carboranes have high thermal and chemical stability, and exceptionally high hydrophobicity, ${ }^{22-24)}$ and we have applied them as hydrophobic core structures of various bioactive compounds, especially ligands of various nuclear receptors, such as retinoid receptors, ${ }^{25)}$ androgen receptor, ${ }^{26)}$ and vitamin D receptor. ${ }^{27)}$ Among the synthesized compounds, we found that the phenyl carborane derivatives 5-7 (Fig. 2) exhibited PR-antagonistic activity. ${ }^{18,20)}$ A docking study of $\mathbf{5}$ with the PR-LBD indicated that the carborane moiety of $\mathbf{5}$ occupies the space corresponding to the steroid CD ring of progesterone (1). ${ }^{18)}$ In addition, the cyano group of 5 was suggested to interact with Gln725 and Arg766 in the PR-LBD, which also interact with 3-carbonyl group of progesterone (1). ${ }^{18)}$ On the other hand, compound 7 having an $m$-carborane core exhibited bidirectional PR ligand activity, namely, it showed PR-antagonistic activity in the low concentration range, and PR-agonistic activity in the high concentration range. ${ }^{20)}$ Compound $\mathbf{8}$ having a 3-trifluoromethyl substituent on the phenyl group showed only antagonistic activity. ${ }^{20)}$ These results indicate that the mode of PR ligand activity is affected by the nature and position of the polar functional group on the phenyl group. Therefore, it is important to investigate the characteristics of a variety of polar functional groups of PR ligands.

The pentafluorosulfanyl $\left(\mathrm{SF}_{5}\right)$ group is known as a "super trifluoromethyl group," because it possesses larger volume, stronger electronegativity, and higher lipophilicity than the trifluoromethyl group. ${ }^{28-30)}$ Because of its unique combination of high polarity and lipophilicity, together with chemical stability, it is attracting considerable interest in the field of medicinal chemistry. ${ }^{29-31)}$ Indeed, many investigations involving the replacement of the trifluoromethyl group in bioactive 


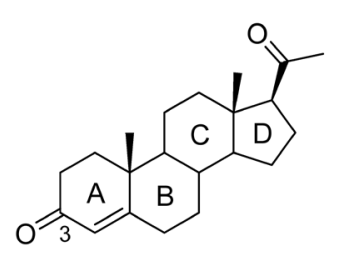

progesterone (1)<smiles>CC#C[C@]1(O)CCC2C3CCC4=CC(=O)CCC4=C3[C@@H](c3ccc(N(C)C)cc3)C[C@@]21C</smiles>

mifepristone (2)<smiles>Cn1c(C#N)ccc1-c1ccc2c(c1)C(C)(C)OC(=S)N2</smiles>

tanaproget (3)<smiles>O=S(=O)(Nc1ccc(Oc2ccccc2)cc1)c1cccc(C(F)(F)F)c1</smiles>

4

Fig. 1. Progesterone $\mathbf{1}$ and Synthetic PR Ligands 2-4

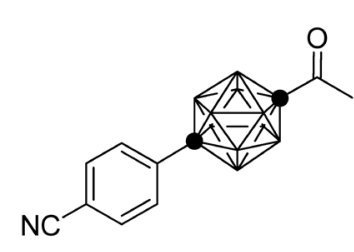

5

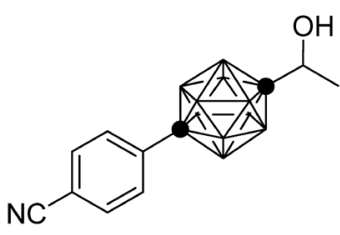

6

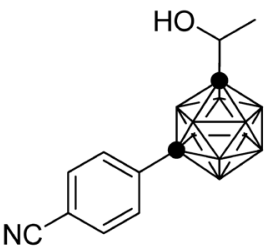

7

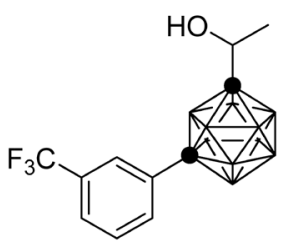

8

\section{8}

Fig. 2. Carborane-Based Non-steroidal PR Antagonists<smiles>Nc1ccc(F)cc1</smiles>

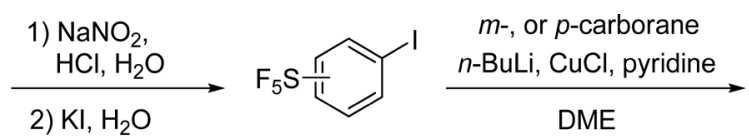

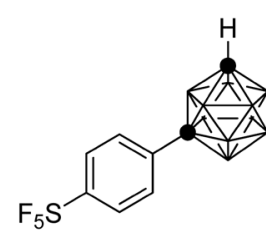

$16(27 \%)$

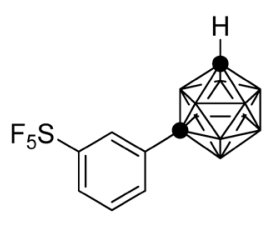

17 (25\%)

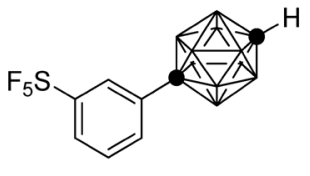

$18(45 \%)$

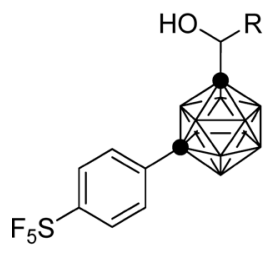

9a $(86 \%)$

$9 b(62 \%)$

9c $71 \%)$

9d $(56 \%)$

9e $(68 \%)$<smiles>[R]C(O)C12C3C4C1C1C2C3C41c1cccc(S(F)(F)(F)(F)F)c1</smiles>

10e $(79 \%)$<smiles></smiles>

$11 \mathrm{a}(90 \%)$ 11e $(92 \%)$

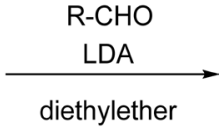

diethylether 
Table 1. PR-Antagonistic Activity of $\mathrm{SF}_{5}$-Containing Carborane Derivatives

\begin{tabular}{|c|c|c|c|c|}
\hline Compound & Carborane & $\mathrm{X}$ & $\mathrm{R}$ & $\mathrm{IC}_{50}(\mu \mathrm{M})$ \\
\hline 9a & $m$ & $4-\mathrm{SF}_{5}$ & $\mathrm{Me}$ & $1.9 \pm 0.07$ \\
\hline $9 b$ & $m$ & $4-\mathrm{SF}_{5}$ & Et & $2.9 \pm 0.23$ \\
\hline $9 \mathrm{c}$ & $m$ & $4-\mathrm{SF}_{5}$ & $n-\operatorname{Pr}$ & $3.1 \pm 0.26$ \\
\hline 9d & $m$ & 4- $\mathrm{SF}_{5}$ & $n-\mathrm{Bu}$ & $4.3 \pm 0.11$ \\
\hline $9 e$ & $m$ & $4-\mathrm{SF}_{5}$ & Cyclopropyl & $2.9 \pm 0.10$ \\
\hline $10 \mathrm{e}$ & $m$ & $3-\mathrm{SF}_{5}$ & Cyclopropyl & $1.7 \pm 0.18$ \\
\hline $11 \mathrm{a}$ & $p$ & $3-\mathrm{SF}_{5}$ & $\mathrm{Me}$ & $0.37 \pm 0.027$ \\
\hline $11 \mathrm{e}$ & $p$ & $3-\mathrm{SF}_{5}$ & Cyclopropyl & $0.42 \pm 0.054$ \\
\hline
\end{tabular}

Table 2. PR-Antagonistic Activity of $p$-Carborane Derivatives Having Different Functional Groups

\begin{tabular}{ccc} 
& \\
\hline Compound & $\mathrm{X}$ & $\mathrm{IC}_{50}(\mu \mathrm{M})$ \\
\hline $\mathbf{1 1}$ & $\mathrm{SF}_{5}$ & $0.42 \pm 0.054$ \\
$\mathbf{1 9}$ & $\mathrm{CN}_{2}$ & $0.045 \pm 0.005$ \\
$\mathbf{2 0}$ & $\mathrm{NO}_{2}$ & $0.051 \pm 0.004$ \\
$\mathbf{2 1}$ & $\mathrm{CF}_{3}$ & $0.35 \pm 0.054$ \\
\hline
\end{tabular}

of alkaline phosphatase assay using the T-47D human breast cancer cell line, in which alkaline phosphatase expression is regulated by PR. The PR-agonistic activity was evaluated in terms of the increase ratio of alkaline phosphatase activity in the presence of test compound alone, while the PR-antagonistic activity was evaluated in terms of inhibition of coexisting progesterone $(1 \mathrm{nM})$-induced alkaline phosphatase activity by the test compound.

All of the synthesized $\mathrm{SF}_{5}$-containing carborane derivatives exhibited PR-antagonistic activity (Table 1). None of the test compounds exhibited PR-agonistic activity. Although compound 7 bearing a $p$-cyanophenyl moiety showed bidirectional PR ligand activity (antagonistic activity at low concentration, and agonistic activity at high concentration), compounds 9a-e having the same skeletal structure as $\mathbf{7}$ did not act as $\mathrm{PR}$ agonists even in the high concentration range. This result indicates that the mode of PR ligand activity can be changed depending upon the nature of the polar functional group on the phenyl group. The antagonistic activity of $\mathbf{9 a}-\mathbf{e}$ having an $m$-carborane core and a 4-pentafluorosulfanylphenyl group was moderate $\left(\mathrm{IC}_{50}\right.$ approx. $\left.2-4 \mu \mathrm{M}\right)$, and the length of the alkyl chain ( $\mathrm{R}$ group) of the secondary alcohol did not greatly affect the potency. The potency of $\mathbf{1 0 e}\left(\mathrm{IC}_{50}=1.7 \mu \mathrm{M}\right)$ having a 3-pentafluorosulfanylphenyl group on $m$-carborane was similar to that of 9a-e. On the other hand, 11a $\left(\mathrm{IC}_{50}=0.37 \mu \mathrm{M}\right)$ and 11e $\left(\mathrm{IC}_{50}=0.42 \mu \mathrm{M}\right)$ having a $p$-carborane and a $3-\mathrm{SF}_{5}$ group, exhibited about 10-fold higher antagonistic activities

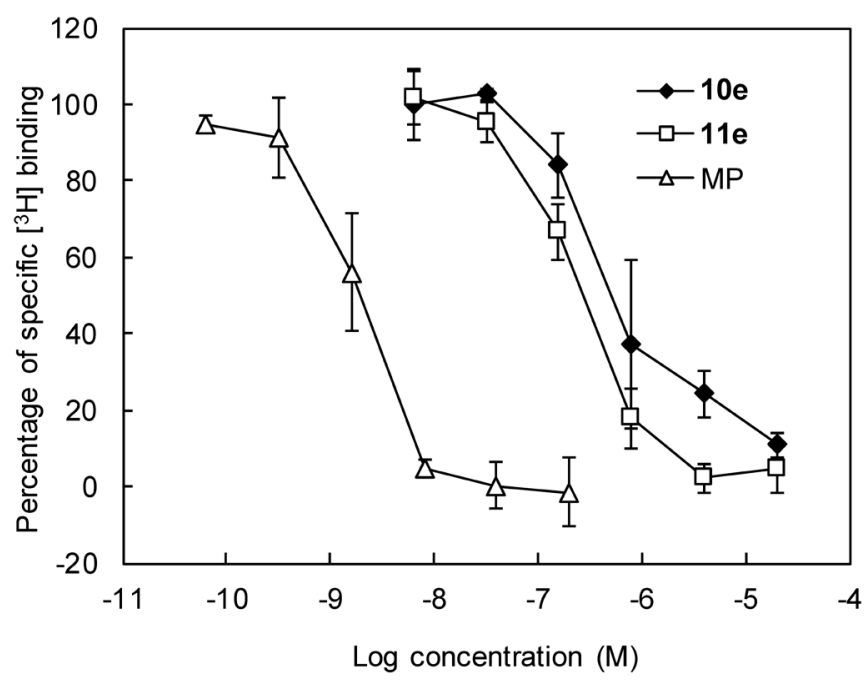

Fig. 3. Competitive Binding Assay of the $\mathrm{SF}_{5}$-Containing Carborane Derivatives

The concentration of $\left[{ }^{3} \mathrm{H}\right]$ progesterone was $4 \mathrm{nM}$. Mifepristone (MP) was used as the positive control.

than the corresponding $m$-carborane derivatives $\mathbf{9}$ and $\mathbf{1 0}$.

To evaluate the effect of polar functional groups, we synthesized compounds 19, 20, and 21, having different polar functional groups on the same skeletal structure of 11e, according to our previous report, ${ }^{18)}$ and examined their PRantagonistic activities (Table 2). Among them, 19 with a cyano group and 20 with a nitro group showed potent PR-antagonistic activity. Compound 11e with a $\mathrm{SF}_{5}$ group and 21 with a trifluoromethyl group showed relatively low PR-antagonistic activity compared to $\mathbf{1 9}$ and $\mathbf{2 0}$. These results suggest that functional groups having $\pi$ electron system such as nitro and cyano group could interact more strongly with PR-LBD than functional groups having multiple fluorine atoms. Compounds 11e and 21 showed comparable antagonistic activity, while $\mathrm{SF}_{5}$ group is stronger electron-withdrawing than trifluoromethyl group, ${ }^{35)}$ which suggests that the electron density of the phenyl ring of the carborane derivatives would not be important for the interaction with PR-LBD, and that the multiple fluorines of $\mathrm{SF}_{5}$ and trifluoromethyl group might play similar function in PR-LBD.

Finally, we examined the PR-binding affinity of selected compounds 10e, and 11e (Fig. 3). The binding affinities were evaluated by means of competitive binding assay using the PR-LBD and $\left[1,2,6,7-{ }^{3} \mathrm{H}\right]$ progesterone. Both $\mathbf{1 0 e}$ and 11e bound to the PR-LBD at submicro- to micromolar concentrations. Compound 11e that exhibited higher PR-antagonistic activity than 10e showed higher binding affinity to the PR-LBD than 10e. These results suggest that the PR-antagonistic activity of these compounds evaluated by T-47D alkaline phosphatase assay was mediated by binding of the compounds to PR.

We designed and synthesized a series of carborane-based PR antagonists having a pentafluorosulfanyl group as the polar functional group. All of the synthesized compounds 9-11 exhibited PR-antagonistic activity, and in particular, the $p$-carborane derivatives 11 showed potent antagonistic activities at submicromolar concentration. The results suggest that the pentafluorosulfanyl group is an effective polar functional group that can interact with the PR-LBD as an alternative to the 3-carbonyl group of progesterone. Although the antago- 
nistic activities of $\mathrm{SF}_{5}$-containing carborane derivatives 9-11 were lower than that of $\mathbf{1 9}$ or $\mathbf{2 0}$ having a cyano group or a nitro group, respectively, further structural optimization might increase the activity. The carborane structure and pentafluorosulfanyl group may prove to be valuable building blocks for the design of ligands not only for PR, but also for other nuclear receptors.

\section{Experimental}

General $\mathrm{SF}_{5}$-containing anilines $\mathbf{1 2}$ and $\mathbf{1 3}$ were supplied from UBE Industries, LTD., Japan. Other reagents were purchased from Sigma-Aldrich (U.S.A.), Tokyo Chemical Industry (Japan), Wako Pure Chemical Industries, Ltd. (Japan), and Kanto Chemicals (Japan) and were used without further purification. NMR spectra were recorded on Bruker AVANCE 400 or Bruker AVANCE 500 spectrometers. Chemical shifts for NMR are reported as parts of per million ( $\mathrm{ppm})$ relative to chloroform (7.27 ppm for ${ }^{1} \mathrm{H}-\mathrm{NMR}$ and $77.23 \mathrm{ppm}$ for $\left.{ }^{13} \mathrm{C}-\mathrm{NMR}\right)$ and benzotrifluoride ( $-63.72 \mathrm{ppm}$ for $\left.{ }^{19} \mathrm{~F}-\mathrm{NMR}\right)$ as an external standard. Coupling patterns are denoted as follows: singlet (s), doublet (d), doublet of doublets (dd), doublet of doublets of doublets (ddd), doublet of triplets (dt), triplet $(\mathrm{t})$, quartet (q), quintet (quin), multiplet (m), broad singlet (brs), and broad multiplet (brm). MS were collected on a Bruker Daltonics microTOF-2focus spectrometer in the negative ion mode. Melting points were obtained on a Yanagimoto micro melting point apparatus without correction. Elemental analyses were carried out by using Yanaco MT-6 CHNCORDER spectrometer.

General Procedure for Synthesis of 14 or 15 A cold solution of $\mathrm{NaNO}_{2}(102 \mathrm{mg}, 1.48 \mathrm{mmol})$ in water $(2.5 \mathrm{~mL})$ was added slowly to a solution of $\mathbf{1 2}$ or $\mathbf{1 3}(306 \mathrm{mg}, 1.40 \mathrm{mmol})$ in conc. $\mathrm{HCl}(1.5 \mathrm{~mL})$ and ice $(2.5 \mathrm{~g})$. The mixture was stirred at $0^{\circ} \mathrm{C}$ for $2 \mathrm{~min}$ and then added slowly to a solution of $\mathrm{KI}$ $(220 \mathrm{mg}, 1.33 \mathrm{mmol})$ in water $(20 \mathrm{~mL})$ at $0^{\circ} \mathrm{C}$. The resulting mixture was stirred for $30 \mathrm{~min}$ on ice and then allowed to warm to r.t. for $1 \mathrm{~h}$, and the product was extracted with dichloromethane. The organic layer was washed with saturated aqueous $\mathrm{NaHCO}_{3}$ solution, dried over sodium sulfate, and concentrated. Purification by silica gel column chromatography (eluent: $n$-hexane) gave iodinated products $\mathbf{1 4}$ or $\mathbf{1 5}$.

3-Iodophenylsulfur Pentafluoride (14)

Colorless oil (87\% yield): ${ }^{1} \mathrm{H}-\mathrm{NMR}\left(400 \mathrm{MHz}, \mathrm{CDCl}_{3}\right) \delta$ : 8.09 (t, $J=2.0 \mathrm{~Hz}, 1 \mathrm{H}), 7.86(\mathrm{~d}, J=8.0 \mathrm{~Hz}, 1 \mathrm{H}), 7.75$ (dd, $J=8.4,2.0 \mathrm{~Hz}, 1 \mathrm{H}), 7.22(\mathrm{dd}, J=8.8,8.0 \mathrm{~Hz}, 1 \mathrm{H}) ;{ }^{19} \mathrm{~F}-\mathrm{NMR}$ $\left(376 \mathrm{MHz}, \mathrm{CDCl}_{3}\right) \delta: 82.81$ (quin, $J=150.1 \mathrm{~Hz}, 1 \mathrm{~F}$ ), 62.53 (d, $J=150.1 \mathrm{~Hz}, 4 \mathrm{~F})$.

\section{4-Iodophenylsulfur Pentafluoride (15)}

Colorless solid (82\% yield): ${ }^{1} \mathrm{H}-\mathrm{NMR}\left(400 \mathrm{MHz}, \mathrm{CDCl}_{3}\right) \delta$ : 7.82 (d, $J=7.2 \mathrm{~Hz}, 2 \mathrm{H}), 7.49$ (d, $J=7.2 \mathrm{~Hz}, 2 \mathrm{H}) ;{ }^{19} \mathrm{~F}-\mathrm{NMR}$ $\left(376 \mathrm{MHz}, \mathrm{CDCl}_{3}\right) \delta: 83.21$ (quin, $J=150.3 \mathrm{~Hz}, 1 \mathrm{~F}$ ), 62.55 (d, $J=150.1 \mathrm{~Hz}, 4 \mathrm{~F})$.

General Procedure for Synthesis of 16-18 A solution of $n$-butyllithium in $n$-hexane $(2.67 \mathrm{M}, 0.8 \mathrm{~mL}, 2.14 \mathrm{mmol})$ was added to a solution of $m$ - or $p$-carborane $(211 \mathrm{mg}, 1.46 \mathrm{mmol})$ in 1,2-dimethoxyethane $(10 \mathrm{~mL})$ at $0^{\circ} \mathrm{C}$ under an $\mathrm{Ar}$ atmosphere, and the mixture was stirred at $0^{\circ} \mathrm{C}$ for $30 \mathrm{~min}$. Copper (I) chloride $(162 \mathrm{mg}, 1.64 \mathrm{mmol})$ was added to the reaction mixture at room temperature. After $1 \mathrm{~h}$, pyridine $(1.5 \mathrm{~mL})$ and pentafluorosulfanylated iodobenzene 14 or $15(500 \mathrm{mg}$, $1.51 \mathrm{mmol}$ ) were added, and the mixture was stirred at $80^{\circ} \mathrm{C}$ for $20 \mathrm{~h}$. After cooling, the reaction mixture was diluted with ethyl acetate, and insoluble materials were filtered off through celite. The filtrate was washed successively with 5\% sodium thiosulfate, $2 \mathrm{M}$ hydrochloric acid, and brine, dried over sodium sulfate, and evaporated. The residue was purified by silica gel column chromatography (eluent: $n$-hexane) to give the products $\mathbf{1 6}-\mathbf{1 8}$.

1-(4-Pentafluoro- $\lambda^{6}$-sulfanylphenyl)-1,7-dicarba-closododecaborane (16)

Yellow solid (27\% yield): ${ }^{1} \mathrm{H}-\mathrm{NMR}\left(400 \mathrm{MHz}, \mathrm{CDCl}_{3}\right) \delta$ : $7.68(\mathrm{~d}, J=7.2 \mathrm{~Hz}, 2 \mathrm{H}), 7.53$ (d, $J=6.8 \mathrm{~Hz}, 2 \mathrm{H}), 3.12$ (brs, 1 $\mathrm{H}), 3.5-1.5$ (brm, $10 \mathrm{H}) ;{ }^{19} \mathrm{~F}-\mathrm{NMR}\left(376 \mathrm{MHz}, \mathrm{CDCl}_{3}\right) \delta: 83.41$ (quin, $J=150.0 \mathrm{~Hz}, 1 \mathrm{~F}), 62.48(\mathrm{~d}, J=150.0 \mathrm{~Hz}, 4 \mathrm{~F})$.

1-(3-Pentafluoro- $\lambda^{6}$-sulfanylphenyl)-1,7-dicarba-closododecaborane (17)

Colorless solid (25\% yield): ${ }^{1} \mathrm{H}-\mathrm{NMR}\left(400 \mathrm{MHz}, \mathrm{CDCl}_{3}\right) \delta$ : $7.81(\mathrm{t}, J=2.0 \mathrm{~Hz}, 1 \mathrm{H}), 7.71(\mathrm{ddd}, J=8.0,4.0,0.8 \mathrm{~Hz}, 1 \mathrm{H})$, $7.59(\mathrm{~d}, J=8.8 \mathrm{~Hz}, 1 \mathrm{H}), 7.39$ (t, $J=8.0 \mathrm{~Hz}, 1 \mathrm{H}), 3.13$ (brs, 1 $\mathrm{H}), 4.0-1.5$ (brm, $10 \mathrm{H}) ;{ }^{19} \mathrm{~F}-\mathrm{NMR}\left(376 \mathrm{MHz}, \mathrm{CDCl}_{3}\right) \delta: 83.13$ (quin, $J=150.1 \mathrm{~Hz}, 1 \mathrm{~F}), 62.53$ (d, $J=150.0 \mathrm{~Hz}, 4 \mathrm{~F})$.

1-(3-Pentafluoro- $\lambda^{6}$-sulfanylphenyl)-1,12-dicarba-closododecaborane (18)

Colorless solid (45\% yield): ${ }^{1} \mathrm{H}-\mathrm{NMR}\left(400 \mathrm{MHz}, \mathrm{CDCl}_{3}\right) \delta$ : $7.62(\mathrm{dt}, J=8.4,2.0 \mathrm{~Hz}, 1 \mathrm{H}), 7.59(\mathrm{dd}, J=2.0,1.6 \mathrm{~Hz}, 1 \mathrm{H})$, $7.37(\mathrm{~d}, J=8.0 \mathrm{~Hz}, 1 \mathrm{H}), 7.30(\mathrm{dd}, J=8.4,8.0 \mathrm{~Hz}, 1 \mathrm{H}), 2.85$ (brs, $1 \mathrm{H}), 3.5-1.5$ (brm, $10 \mathrm{H})$; ${ }^{19} \mathrm{~F}-\mathrm{NMR}\left(376 \mathrm{MHz}, \mathrm{CDCl}_{3}\right.$ ) $\delta$ : 83.10 (quin, $J=150.1 \mathrm{~Hz}, 1 \mathrm{~F}$ ), 62.48 (d, $J=150.1 \mathrm{~Hz}, 4 \mathrm{~F}$ ).

General Procedure for Synthesis of 9-11 A solution of lithium diisopropylamide in a mixture of $n$-hexane and tetrahydrofuran $(1.1 \mathrm{M}, 0.14 \mathrm{~mL}, 0.16 \mathrm{mmol})$ was added to a solution of $\mathbf{1 6}-\mathbf{1 8}(48 \mathrm{mg}, 0.14 \mathrm{mmol})$ in THF $(2 \mathrm{~mL})$ at $-78^{\circ} \mathrm{C}$ under an $\mathrm{Ar}$ atmosphere, and the mixture was stirred at $-78^{\circ} \mathrm{C}$ for $20 \mathrm{~min}$. The appropriate aldehyde (2.0-10 equiv.) was added to the reaction mixture at $-78^{\circ} \mathrm{C}$. The resulting mixture was stirred at $-78^{\circ} \mathrm{C}$ for $1 \mathrm{~h}$, then poured into saturated ammonium chloride, and extracted with ethyl acetate. The organic layer was washed with water and brine, dried over sodium sulfate, and evaporated. The residue was purified by silica gel column chromatography (eluent: $n$-hexane/ethyl acetate, 10/1) to give the racemic alcohols 9-11.

1-(4-Pentafluoro- $\lambda^{6}$-sulfanylphenyl)-7-(1-hydroxyethyl)-1,7dicarba-closo-dodecaborane (9a)

Colorless oil (86\% yield): ${ }^{1} \mathrm{H}-\mathrm{NMR}\left(400 \mathrm{MHz}, \mathrm{CDCl}_{3}\right) \delta$ : 7.65 (d, $J=7.2 \mathrm{~Hz}, 2 \mathrm{H}), 7.54(\mathrm{~d}, J=6.8 \mathrm{~Hz}, 2 \mathrm{H}), 4.14-4.07$ (m, $1 \mathrm{H}), 3.5-1.5$ (brm, $10 \mathrm{H}), 1.89$ (d, $J=4.8 \mathrm{~Hz}, 1 \mathrm{H}), 1.34$ $(\mathrm{d}, J=5.2 \mathrm{~Hz}, 3 \mathrm{H}) ;{ }^{19} \mathrm{~F}-\mathrm{NMR}\left(376 \mathrm{MHz}, \mathrm{CDCl}_{3}\right) \delta: 83.10$ (quin, $J=150.1 \mathrm{~Hz}, 1 \mathrm{~F}), 62.48(\mathrm{~d}, J=150.0 \mathrm{~Hz}, 4 \mathrm{~F})$; high resolution (HR)MS electrospray ionization $\left(\mathrm{ESI}^{-}\right)$Calcd for $\mathrm{C}_{10} \mathrm{H}_{18} \mathrm{~B}_{10} \mathrm{~F}_{5} \mathrm{OS}[\mathrm{M}-\mathrm{H}]^{-}$: 391.1929. Found: 391.1937.

1-(4-Pentafluoro- $\lambda^{6}$-sulfanylphenyl)-7-(1-hydroxypropyl)-1,7dicarba-closo-dodecaborane (9b)

Colorless oil (62\% yield): ${ }^{1} \mathrm{H}-\mathrm{NMR}\left(400 \mathrm{MHz}, \mathrm{CDCl}_{3}\right) \delta$ : $7.66(\mathrm{~d}, J=7.2 \mathrm{~Hz}, 2 \mathrm{H}), 7.53(\mathrm{~d}, J=6.8 \mathrm{~Hz}, 2 \mathrm{H}), 3.76-3.72$ (m, $1 \mathrm{H}), 3.0-1.5$ (brm, $10 \mathrm{H}), 1.88(\mathrm{~d}, J=5.2 \mathrm{~Hz}, 1 \mathrm{H})$, 1.75-1.70 (m, $1 \mathrm{H}), 1.43-1.37(\mathrm{~m}, 1 \mathrm{H}), 1.02(\mathrm{t}, J=5.6 \mathrm{~Hz}, 3$ $\mathrm{H}) ;{ }^{19} \mathrm{~F}-\mathrm{NMR}\left(376 \mathrm{MHz}, \mathrm{CDCl}_{3}\right) \delta: 83.12$ (quin, $J=150.2 \mathrm{~Hz}$, $1 \mathrm{~F}), 62.49(\mathrm{~d}, J=150.1 \mathrm{~Hz}, 4 \mathrm{~F})$; HRMS (ESI ${ }^{-}$) Calcd for $\mathrm{C}_{11} \mathrm{H}_{20} \mathrm{~B}_{10} \mathrm{~F}_{5} \mathrm{OS}[\mathrm{M}-\mathrm{H}]^{-}$: 405.2086. Found: 405.2094.

1-(4-Pentafluoro- $\lambda^{6}$-sulfanylphenyl)-7-(1-hydroxybutyl)-1,7dicarba-closo-dodecaborane (9c)

Colorless oil (71\% yield): ${ }^{1} \mathrm{H}-\mathrm{NMR}\left(400 \mathrm{MHz}, \mathrm{CDCl}_{3}\right) \delta$ : 
7.66 (d, $J=7.2 \mathrm{~Hz}, 2 \mathrm{H}), 7.53$ (d, $J=8.0 \mathrm{~Hz}, 2 \mathrm{H}), 3.85-3.82$ (m 1H), 3.0-1.5 (brm, $10 \mathrm{H}), 1.86(\mathrm{~d}, J=4.8 \mathrm{~Hz}, 1 \mathrm{H})$, $1.61-1.57(\mathrm{~m}, 1 \mathrm{H}), 1.42-1.35(\mathrm{~m}, 3 \mathrm{H}), 0.92$ (t, $J=5.8 \mathrm{~Hz}, 3$ $\mathrm{H}) ;{ }^{19} \mathrm{~F}-\mathrm{NMR}\left(376 \mathrm{MHz}, \mathrm{CDCl}_{3}\right) \delta: 83.12$ (quin, $J=150.1 \mathrm{~Hz}$, $1 \mathrm{~F}), 62.49(\mathrm{~d}, J=150.8 \mathrm{~Hz}, 4 \mathrm{~F})$; HRMS (ESI $\left.{ }^{-}\right)$Calcd for $\mathrm{C}_{12} \mathrm{H}_{22} \mathrm{~B}_{10} \mathrm{~F}_{5} \mathrm{OS}[\mathrm{M}-\mathrm{H}]^{-}:$419.2242. Found: 419.2250 .

1-(4-Pentafluoro- $\lambda^{6}$-sulfanylphenyl)-7-(1-hydroxypentyl)-1,7dicarba-closo-dodecaborane (9d)

Colorless oil (56\% yield): ${ }^{1} \mathrm{H}-\mathrm{NMR}\left(400 \mathrm{MHz}, \mathrm{CDCl}_{3}\right) \delta$ : 7.65 (d, $J=7.2 \mathrm{~Hz}, 2 \mathrm{H}), 7.53$ (d, $J=7.2 \mathrm{~Hz}, 2 \mathrm{H}), 3.84-3.82$ (m, $1 \mathrm{H}), 3.0-1.5$ (brm, $10 \mathrm{H}), 1.87$ (d, $J=4.8,1 \mathrm{H}), 1.67-1.62$ $(\mathrm{m}, 1 \mathrm{H}), 1.43-1.32(\mathrm{~m}, 5 \mathrm{H}), 0.92(\mathrm{t}, J=5.8,3 \mathrm{H}) ;{ }^{19} \mathrm{~F}-\mathrm{NMR}$ $\left(376 \mathrm{MHz}, \mathrm{CDCl}_{3}\right) \delta: 83.16$ (quin, $J=150.3 \mathrm{~Hz}, 1 \mathrm{~F}$ ), 64.30 (d, $J=150.0 \mathrm{~Hz}, 4 \mathrm{~F})$; HRMS $\left(\mathrm{ESI}^{-}\right)$Calcd for $\mathrm{C}_{13} \mathrm{H}_{25} \mathrm{~B}_{10} \mathrm{~F}_{5} \mathrm{OS}$ $[\mathrm{M}-\mathrm{H}]^{-}:$433.2399. Found: 433.2407.

1-(4-Pentafluoro- $\lambda^{6}$-sulfanylphenyl)-7-(1-cyclopropyl-1hydroxymethyl)-1,7-dicarba-closo-dodecaborane (9e)

Colorless oil $\left(68 \%\right.$ yield): ${ }^{1} \mathrm{H}-\mathrm{NMR}\left(400 \mathrm{MHz}, \mathrm{CDCl}_{3}\right) \delta$ : $7.67(\mathrm{~d}, J=7.2 \mathrm{~Hz}, 2 \mathrm{H}), 7.55(\mathrm{~d}, J=7.2 \mathrm{~Hz}, 2 \mathrm{H}), 3.20$ (q, $J=3.5 \mathrm{~Hz}, 1 \mathrm{H}), 3.0-1.5$ (brm, $10 \mathrm{H}), 1.93(\mathrm{~d}, J=3.6 \mathrm{~Hz}, 1$ $\mathrm{H}), 1.28-0.98(\mathrm{~m}, 1 \mathrm{H}), 0.73-0.60(\mathrm{~m}, 2 \mathrm{H}), 0.45-0.38(\mathrm{~m}, 2$ $\mathrm{H}) ;{ }^{19} \mathrm{~F}-\mathrm{NMR}\left(376 \mathrm{MHz}, \mathrm{CDCl}_{3}\right) \delta: 83.12$ (quin, $J=149.8 \mathrm{~Hz}$, $1 \mathrm{~F}), 62.49(\mathrm{~d}, J=150.1 \mathrm{~Hz}, 4 \mathrm{~F})$; HRMS (ESI $\left.{ }^{-}\right)$Calcd for $\mathrm{C}_{12} \mathrm{H}_{20} \mathrm{~B}_{10} \mathrm{~F}_{5} \mathrm{OS}[\mathrm{M}-\mathrm{H}]^{-}$: 417.2086. Found: 417.2094.

1-(3-Pentafluoro- $\lambda^{6}$-sulfanylphenyl)-7-(1-cyclopropyl-1hydroxymethyl)-1,7-dicarba-closo-dodecaborane (10e)

Colorless oil (79\% yield): ${ }^{1} \mathrm{H}-\mathrm{NMR}\left(400 \mathrm{MHz}, \mathrm{CDCl}_{3}\right) \delta$ : $7.82(\mathrm{dd}, J=2.0,1.6 \mathrm{~Hz}, 1 \mathrm{H}), 7.71(\mathrm{ddd}, J=8.4,2.4,1.2 \mathrm{~Hz}$, $1 \mathrm{H}), 7.61(\mathrm{~d}, J=8.8 \mathrm{~Hz}, 1 \mathrm{H}), 7.39(\mathrm{dd}, J=8.4,7.6 \mathrm{~Hz}, 1$ H), 3.20 (q, $J=4.4 \mathrm{~Hz}, 1 \mathrm{H}), 3.0-1.5(\mathrm{brm}, 10 \mathrm{H}), 1.95$ (d, $J=4.8 \mathrm{~Hz}, 1 \mathrm{H}), 1.04-0.97(\mathrm{~m}, 1 \mathrm{H}), 0.74-0.63(\mathrm{~m}, 2 \mathrm{H})$, 0.54-0.48 (m, $2 \mathrm{H})$; ${ }^{13} \mathrm{C}-\mathrm{NMR}\left(126 \mathrm{MHz}\right.$, methanol- $\left.d_{4}\right) \delta$ : 155.0 (quin, $J=17.6 \mathrm{~Hz}$ ), 138.2, 132.7, 130.8, 127.8 (quin, $J=4.5 \mathrm{~Hz}$ ), 126.4 (quin, $J=4.8 \mathrm{~Hz}$ ), 85.4, 77.1, 76.8, 19.0, 5.47, 4.03; ${ }^{19} \mathrm{~F}-\mathrm{NMR}\left(376 \mathrm{MHz}, \mathrm{CDCl}_{3}\right) \delta: 81.64$ (quin, $J=148.0 \mathrm{~Hz}$, $1 \mathrm{~F}), 60.83(\mathrm{~d}, J=147.9 \mathrm{~Hz}, 4 \mathrm{~F})$; HRMS $\left(\mathrm{ESI}^{-}\right)$Calcd for $\mathrm{C}_{12} \mathrm{H}_{20} \mathrm{~B}_{10} \mathrm{~F}_{5} \mathrm{OS}[\mathrm{M}-\mathrm{H}]^{-}:$417.2086. Found: 417.2090.

1 - (3 - Pent af l uoro- $\lambda^{6}$ - sulfanylpheny 1$)-12$ - ( 1 hydroxyethyl)-1,12-dicarba-closo-dodecaborane (11a)

Colorless oil ( $90 \%$ yield): ${ }^{1} \mathrm{H}-\mathrm{NMR}\left(400 \mathrm{MHz}, \mathrm{CDCl}_{3}\right)$ $\delta: 7.63$ (ddd, $J=8.0,2.0,0.8 \mathrm{~Hz}, 1 \mathrm{H}), 7.59(\mathrm{t}, J=2.0 \mathrm{~Hz}, 1$ H), $7.38(\mathrm{~d}, J=8.0 \mathrm{~Hz}, 1 \mathrm{H}), 7.30(\mathrm{dd}, J=8.0,7.2 \mathrm{~Hz}, 1 \mathrm{H})$, 3.77 (m, $1 \mathrm{H}), 3.5-1.5$ (br, m, $10 \mathrm{H}), 1.65(\mathrm{~d}, J=6 \mathrm{~Hz}, 1 \mathrm{H})$, $1.13(\mathrm{~d}, J=6.4 \mathrm{~Hz}, 1 \mathrm{H}) ;{ }^{13} \mathrm{C}-\mathrm{NMR}\left(126 \mathrm{MHz}\right.$, methanol- $\left.d_{4}\right)$ $\delta$ : 154.9 (quin, $J=17.4 \mathrm{~Hz}$ ), 138.9, 132.0, 130.5, 127.5 (quin, $J=4.5 \mathrm{~Hz}$ ), 125.8 (quin, $J=4.7 \mathrm{~Hz}$ ), 90.2, 82.6, 69.9, 23.6; ${ }^{19} \mathrm{~F}-\mathrm{NMR}\left(376 \mathrm{MHz}\right.$, methanol- $d_{4}$ ) $\delta: 81.74$ (quin, $J=148.0 \mathrm{~Hz}$, $1 \mathrm{~F}), 60.78$ (d, $J=148.0 \mathrm{~Hz}, 4 \mathrm{~F})$; HRMS (ESI $\left.{ }^{-}\right)$Calcd for $\mathrm{C}_{10} \mathrm{H}_{18} \mathrm{~B}_{10} \mathrm{~F}_{5} \mathrm{OS}[\mathrm{M}-\mathrm{H}]^{-}$: 391.1929. Found: 391.1938 .

1-(3-Pentafluoro- $\lambda^{6}$-sulfanylphenyl)-12-(1-cyclopropyl-1hydroxymethyl)-1,12-dicarba-closo-dodecaborane (11e)

Colorless oil (92\% yield): ${ }^{1} \mathrm{H}-\mathrm{NMR}\left(400 \mathrm{MHz}, \mathrm{CDCl}_{3}\right) \delta$ : $7.63-7.60(\mathrm{~m}, 2 \mathrm{H}), 7.39(\mathrm{~d}, J=6.4 \mathrm{~Hz}, 1 \mathrm{H}), 7.30(\mathrm{dd}, J=6.8$, $6.0 \mathrm{~Hz}, 1 \mathrm{H}), 2.88$ (q, $J=3.5 \mathrm{~Hz}, 1 \mathrm{H}), 3.5-1.5$ (br, m, 10 $\mathrm{H}), 1.69(\mathrm{~d}, J=4.0 \mathrm{~Hz}, 1 \mathrm{H}), 0.83-0.76(\mathrm{~m}, 1 \mathrm{H}), 0.64-0.51$ $(\mathrm{m}, 2 \mathrm{H}), 0.34-0.25(\mathrm{~m}, 2 \mathrm{H})$; HRMS (ESI $\left.{ }^{-}\right)$Calcd for $\mathrm{C}_{12} \mathrm{H}_{20} \mathrm{~B}_{10} \mathrm{~F}_{5} \mathrm{OS}[\mathrm{M}-\mathrm{H}]^{-}:$: 417.2086. Found: 417.2087.

1 -(3 - Cyanophenyl)-12-(1 - cyclopropyl-1-hydroxymethyl)-1,12-dicarba-closo-dodecaborane (19)

Colorless solid: mp $145-147^{\circ} \mathrm{C} ;{ }^{1} \mathrm{H}-\mathrm{NMR}\left(500 \mathrm{MHz}, \mathrm{CDCl}_{3}\right)$ $\delta$ : $7.52(\mathrm{~m}, 2 \mathrm{H}), 7.45$ (t, $J=1.6 \mathrm{~Hz}, 1 \mathrm{H}), 7.31(\mathrm{t}, J=7.6 \mathrm{~Hz}, 1$
H), 2.9-1.6 (brm, $10 \mathrm{H}), 2.88$ (dd, $J=8.3,1.2 \mathrm{~Hz}, 1 \mathrm{H}) 1.70$ (s, $1 \mathrm{H}), 0.83-0.76(\mathrm{~m}, 1 \mathrm{H}), 0.60-0.59(\mathrm{~m}, 2 \mathrm{H}), 0.34-0.25(\mathrm{~m}$, $2 \mathrm{H}) ;{ }^{13} \mathrm{C}-\mathrm{NMR}\left(126 \mathrm{MHz}, \mathrm{CDCl}_{3}\right) \delta, 137.9,132.0,131.7,131.0$, 129.2, 118.3, 112.7, 87.0, 81.5, 17.9, 4.8, 3.2; HRMS $\left(\mathrm{ESI}^{-}\right)$ Calcd for $\mathrm{C}_{14} \mathrm{H}_{22} \mathrm{~B}_{10} \mathrm{~F}_{3} \mathrm{O}_{3}\left[\mathrm{M}+\mathrm{HCOO}^{-}\right.$: 362.2530. Found: 362.2534

1-(3-Nitrophenyl)-12-(1-cyclopropyl-1-hydroxymethyl)-1,12dicarba-closo-dodecaborane (20)

Colorless solid: ${ }^{1} \mathrm{H}-\mathrm{NMR}\left(400 \mathrm{MHz}, \mathrm{CDCl}_{3}\right) \delta: 8.09(\mathrm{~m}, 2$ H), $7.54(\mathrm{ddd}, J=8.0,3.2,1.8 \mathrm{~Hz}, 1 \mathrm{H}), 7.37(\mathrm{t}, J=8.0 \mathrm{~Hz}, 1$ H), 3.3-2.3 (brm, $10 \mathrm{H}), 2.87$ (dd, $J=8.3,5.3 \mathrm{~Hz}, 1 \mathrm{H}$ ), 1.68 $(\mathrm{d}, J=5.0 \mathrm{~Hz}, 1 \mathrm{H}), 0.82-0.75(\mathrm{~m}, 1 \mathrm{H}), 0.64-0.54(\mathrm{~m}, 2 \mathrm{H})$, $0.32-0.27(\mathrm{~m}, 2 \mathrm{H}) ;{ }^{13} \mathrm{C}-\mathrm{NMR}\left(126 \mathrm{MHz}, \mathrm{CDCl}_{3}\right) \delta, 148.1$, 138.4, 133.3, 129.3, 123.5, 122.5, 17.9, 5.0, 3.2. Anal Calcd for $\mathrm{C}_{12} \mathrm{~B}_{10} \mathrm{H}_{21} \mathrm{NO}_{3}$ : N, 4.18; C, 42.97; H, 6.31. Found: N, 4.08; C, 42.71; H, 6.15 .

1 -(3 -Trifluoromethylphenyl)-12-(1-cyclopropyl-1hydroxymethyl)-1,12-dicarba-closo-dodecaborane (21)

Colorless solid: mp $76-78^{\circ} \mathrm{C}$; ${ }^{1} \mathrm{H}-\mathrm{NMR}\left(500 \mathrm{MHz}, \mathrm{CDCl}_{3}\right)$ $\delta: 7.48(\mathrm{~d}, J=7.7 \mathrm{~Hz}, 1 \mathrm{H}), 7.46(\mathrm{~s}, 1 \mathrm{H}) 7.41(\mathrm{~d}, J=8.4 \mathrm{~Hz}, 1$ $\mathrm{H}), 7.31(\mathrm{~d}, J=7.9 \mathrm{~Hz}, 1 \mathrm{H}), 3.3-2.3(\mathrm{br}, \mathrm{m}, 10 \mathrm{H}), 2.87$ (dd, $J=8.3,4.9 \mathrm{~Hz}, 1 \mathrm{H}) 1.67(\mathrm{~d}, J=5.0 \mathrm{~Hz}, 1 \mathrm{H}), 0.83-0.75(\mathrm{~m}, 1$ $\mathrm{H}), 0.64-0.56(\mathrm{~m}, 1 \mathrm{H}), 0.55-0.49(\mathrm{~m}, 1 \mathrm{H}), 0.35-0.22(\mathrm{~m}, 2$ $\mathrm{H}) ;{ }^{13} \mathrm{C}-\mathrm{NMR}\left(126 \mathrm{MHz}, \mathrm{CDCl}_{3}\right) \delta: 137.5,130.8(\mathrm{q}, J=31.5)$, $130.8,128.9,125.5$ (q, $J=3.8), 124.2$ (q, $J=3.8), 123.9$ (q, $J=273.4$ ), 86.8, 82.4, 17.9, 5.0, 3.3; HRMS (ESI ${ }^{-}$) Calcd for $\mathrm{C}_{14} \mathrm{H}_{22} \mathrm{~B}_{10} \mathrm{~F}_{3} \mathrm{O}_{3}[\mathrm{M}+\mathrm{HCOO}]^{-}:$405.2451. Found: 405.2451.

Alkaline Phosphatase Assay Using T-47D Cells T-47D breast-carcinoma cells were cultured in RPMI 1640 medium with $10 \%(\mathrm{v} / \mathrm{v})$ fetal bovine serum. Cells were plated in 96 -well plates at $10^{4}$ cell/well and incubated overnight $\left(37^{\circ} \mathrm{C}\right.$, $5 \% \mathrm{CO}_{2}$ in air). The next day, the medium was replaced with fresh medium containing test compound, and incubation was continued for $24 \mathrm{~h}$. Then, the medium was aspirated and the cells were fixed with $100 \mu \mathrm{L}$ of $1.8 \%$ formalin (in phosphate buffered saline (PBS)). The fixed cells were washed with PBS and $75 \mu \mathrm{L}$ of assay buffer $(1 \mathrm{mg} / \mathrm{mL} p$-nitrophenol phosphate in diethanolamine water solution, $\mathrm{pH} 9.0,2 \mathrm{mM} \mathrm{MgCl}_{2}$ ) was added. The mixture was incubated at room temperature with shielding from light for $2 \mathrm{~h}$, and then the reaction was terminated by the addition of $100 \mu \mathrm{L}$ of $\mathrm{NaOH}$. The absorbance at $405 \mathrm{~nm}$ was measured.

hPR-Binding Assay hPR-Binding assay was performed using recombinant hPR-LBD purchased from Invitrogen (A15672). hPR-LBD was diluted with buffer $(20 \mathrm{mM}$ Tris$\mathrm{HCl}, 300 \mathrm{mM} \mathrm{NaCl}, 1 \mathrm{mM}$ EDTA, $5 \mathrm{mM}$ DTT, pH 8.0) to $14 \mu \mathrm{g} / \mathrm{mL}$ of total protein and $300 \mu \mathrm{L}$ aliquots were incubated in the dark at $4^{\circ} \mathrm{C}$ with $4 \mathrm{nM}\left[1,2,6,7-{ }^{3} \mathrm{H}\right]$ progesterone (PerkinElmer, Inc., U.S.A.) and reference or test compounds (dissolved in dimethyl sulfoxide (DMSO); final concentration of DMSO was 3\%). Nonspecific binding was assessed by addition of a 200 -fold excess of nonradioactive progesterone. After $24 \mathrm{~h}, 30 \mu \mathrm{L}$ of Dextran T-70/c-globulin-coated charcoal suspension was added to the ligand/protein mixtures $(1 \%$ activated charcoal, $0.05 \% \gamma$-globulin, $0.05 \%$ Dextran 70 , final concentrations) and incubated at $4{ }^{\circ} \mathrm{C}$ for $5 \mathrm{~min}$. The charcoal was removed by centrifugation for $5 \mathrm{~min}$ at $1300 \times \boldsymbol{g}$, and the radioactivity of the supernatant was measured in Ultima Gold scintillation cocktail (PerkinElmer, Inc.) by using a liquid scintillation counter. All experiments were performed in duplicate. 
Acknowledgments This research was partly supported by JSPS KAKENHI Grant Number 18K06546 (to SM), Sasagawa Scientific Research Grant from The Japan Science Society, and JSPS Core-to-Core Program, A, and Advanced Research Networks the Platform Project for Supporting Drug Discovery and Life Science Research funded by Japan Agency for Medical Research and Development (AMED).

Conflict of Interest The authors declare no conflict of interest.

\section{References}

1) Mangelsdorf D. J., Thummel C., Beato M., Herrlich P., Schuetz G., Umesono K., Blumberg B., Kastner P., Mark M., Chambon P., Evans R.M., Cell, 83, 835-839 (1995).

2) Zhang Z., Funk C., Glasser S. R., Mulholland J., Endocrinology, 135, 1256-1263 (1994)

3) Lydon J. P., Demayo F. J., Funk C. R., Mani S. K., Hughes A. R., Montgomery C. A. Jr., Shyamala G., Conneely O. M., O’Malley B. W., Genes Dev., 9, 2266-2278 (1995).

4) Aupperlee M. D., Smith K. T., Kariagina A., Haslam S. Z., Endocrinology, 146, 3577-3588 (2005).

5) Suzuki T., Sasano H., Kimura N., Tamura M., Fukaya T., Yajima A., Nagura H., Hum. Reprod., 9, 1589-1595 (1994).

6) Mani S. K., Allen J. M. C., Clark J. H., Blaustein J. D., O’Malley B. W., Science, 265, 1246-1269 (1994).

7) Torgerson D. J., Bell-Syer S. E., JAMA, 285, 2891-2897 (2001).

8) Chabbert-Buffet N., Meduri G., Bouchard P., Spitz I. M., Hum. Reprod. Update, 11, 293-307 (2005).

9) Bouchard P., Chabbert-Buffet N., Fauser B. C., Fertil. Steril., 96, 1175-1189 (2011)

10) Teutsch G., Philibert D., "Human Reproduction," ed. by Edwards R. G., Oxford University Press, Oxford, England, 1994, Vol. 9, p. 12, Suppl. 1.

11) Fu J., Song H., Zhou M., Zhu H., Wang Y., Chen H., Huang W., Cochrane Database Syst. Rev., 7, CD009881 (2017).

12) Steinauer J., Pritts E. A., Jackson R., Jacoby A. F., Obstet. Gynecol., 103, 1331-1336 (2004).

13) Poole A. J., Li Y., Kim Y., Lin S. C., Lee W. H., Lee E. Y., Science, 314, 1467-1470 (2006).

14) Madauss K. P., Stewart E. L., Williams S. P., Med. Res. Rev., 27,
374-400 (2007).

15) Fensome A., Bender R., Chopra R., Cohen J., Collins M. A., Hudak V., Malakian K., Lockhead S., Olland A., Svenson K., Terefenko E. A., Unwalla R. J., Wilhelm J. M., Wolfrom S., Zhu Y., Zhang Z., Zhang P., Winneker R. C., Wrobel J., J. Med. Chem., 48, 5092-5095 (2005)

16) Yamada A., Kazui Y., Yoshioka H., Tanatani A., Mori S., Kagechika H., Fujii S., ACS Med., Chem. Lett., 7, 1028-1033 (2016).

17) Fujii S., Yamada A., Nakano E., Takeuchi Y., Mori S., Masuno H., Kagechika H., Eur. J. Med. Chem., 84, 264-277 (2014).

18) Fujii S., Nakano E., Yanagida N., Mori S., Masuno H., Kagechika H., Bioorg. Med. Chem., 22, 5329-5337 (2014).

19) Mori S., Takagaki R., Fujii S., Matsumura M., Tanatani A., Kagechika H., Tetrahedron Asymmetry, 25, 1505-1512 (2014).

20) Mori S., Takagaki R., Fujii S., Uruchibara K., Tanatani A., Kagechika H., Chem. Pharm. Bull., 65, 1051-1057 (2017).

21) Wade K., Chem. Br., 11, 177 (1975).

22) Bregadze V. I., Chem. Rev., 92, 209-223 (1992).

23) Hawthorne M. F., Angew. Chem. Int. Ed. Engl., 32, 950-984 (1993).

24) Soloway A. H., Tjarks W., Barnum J. G., Rong F. G., Barth R. F., Codogni I. M., Wilson J. G., Chem. Rev., 98, 1515-1562 (1998).

25) Ohta K., Iijima T., Kawachi E., Kagechika H., Endo Y., Bioorg. Med. Chem. Lett., 14, 5913-5918 (2004).

26) Fujii S., Goto T., Ohta K., Hashimoto Y., Suzuki T., Ohta S., Endo Y., J. Med. Chem., 48, 4654-4662 (2005).

27) Fujii S., Masuno H., Taoda Y., Kano A., Wongmayura A., Nakabayashi M., Ito N., Shimizu M., Kawachi E., Hirano T., Endo Y., Tanatani A., Kagechika H., J. Am. Chem. Soc., 133, 20933-20941 (2011).

28) Verma R., Kirchmeier R., Shreeve J., "Advances in Inorganic Chemistry," Elsevier, 1994, pp. 125-169.

29) Altomonte S., Zanda M., J. Fluor. Chem., 143, 57-93 (2012).

30) Savoie P. R., Welch J. T., Chem. Rev., 115, 1130-1190 (2015).

31) Sowaileh M. F., Hazlitt R. A., Colby D. A., ChemMedChem, 12, 1481-1490 (2017)

32) Welch J. T., Lim D. S., Bioorg. Med. Chem., 15, 6659-6666 (2007).

33) Coteron J. M., Marco M., Esquivias J., et al., J. Med. Chem., 54, 5540-5561 (2011).

34) Jin J., Zhou Y., Yang D., Zhang Q., Wang M.-W., Lu W., Arch. Pharm. Chem., Life Sci., 351, e1800175 (2018).

35) Sheppard W. A., J. Am. Chem. Soc., 84, 3072-3079 (1962). 